Hossein A. Abbasi' / Seyed M. Karimi ${ }^{2}$

\title{
Children's Gender and Men's Income: Evidence from Iran
}

\author{
${ }^{1}$ Economics Department, University of Maryland, 3114 Tydings Hall, 7343 Preinkert Dr., College Park, MD 20742, USA, E-mail: \\ abbasi@econ.umd.edu \\ ${ }^{2}$ Department of Interdisciplinary Arts and Sciences, University of Washington Tacoma, GWP 228, Box 358436, 1900 Commerce \\ Street, Tacoma, WA 98402, USA, E-mail: skarimi2@uw.edu
}

\begin{abstract}
:
In many societies, men work for more hours and acquire higher wages if they have sons versus daughters. Gender bias, higher returns to male children's human capital, and higher costs of raising male children are hypothesized to explain this behavior. Among these, gender bias has received stronger support from empirical studies. Using a four-year panel dataset, we show that a different institutional setting may make men respond to their children's gender differently. We study men's income in a dotal society, Iran, where families are expected to provide dowry for their marrying daughters. We show that, in contrast to the findings in developed countries, Iranian men earn more income when they have daughters versus sons, and we argue that the institution of marriage is the major reason for this unconventional finding.
\end{abstract}

Keywords: children's gender, man's income, marriage, dotal society

JEL classification: J12, J13, J16, J22, J24

DOI: $10.1515 /$ rmeef-2016-0028

\section{Introduction}

In this paper, we examine men's labor market responses to their children's gender and the role that the institution of dowry plays in forming the responses. We have two motivations: first, in many developing countries, especially in the Middle East, a male parent is the main breadwinner of his family and usually makes the major household decisions about investing in children's human capital (World Bank 2012), yet, there is strikingly little empirical evidence of the man's behavior in labor market related to having child or children's gender. Second, institutions affecting households' investment on their children's human capital are largely different in developing countries than those in developed countries where the literature has developed. Therefore, households' responses to children's gender may greatly vary compared to those in the developed world.

Evidence from developed countries shows that fathers who have sons are more active in the labor market than those who have daughters (Lundberg and Rose 2002; Choi, Joesch, and Lundberg 2008). The biased behavior has been explained by son preference, higher cost of raising sons, and higher expected returns to sons' human capital. The theories suggest that societies' different institutions can play a role in a man's response to his children's gender. The response then may vary by societies' structures and institutions. Accordingly, in a dotal society - where an integral component of marriage is bringing of a dowry by the bride - a man's optimal choice in labor market may be greatly different than that in a modern society.

This paper is an attempt to investigate the role of social institutions - namely, the institution of dowry - in forming a man's labor market reactions to his children's gender and to shed new light on the understanding of households' investment in next generation's future when societies impose different limitations on boys and girls. This paper therefore relates to the literature that examines the effect of children's gender on parental labor market behavior. In addition, it presents systematic empirical analyses to explain the measured responses. ${ }^{1}$

In Iranian tradition, a typical dowry (or jahaziyeh in Farsi) includes everything that is required to make a formerly prepared dwelling by a groom ready to move in. It typically contains vestments, carpet, furniture, kitchen electrical and non-electrical appliances, other durables and paraphernalia, jewelry, and even some food and grocery to start a living. Given the extent of the components of a dowry, it is evident that dowry is a very large outlay for an average Iranian household, especially in the presence of credit constraints. We have not found an estimation of the costs of dowry across income groups in Iran, ${ }^{2}$ but our approximations from supplementary datasets clearly indicate the colossal size of dowry costs in comparison to annual income of an average household (Appendix A). 
The early 1990s Iran was a partly dotal society where the dowry tradition was strongly practiced. Moreover, there was significant variation in the roles considered for girls and boys in rural and urban areas. While girls were increasingly seeking higher education and were considering economically active roles for themselves in large cities, marriage and housekeeping were considered as the pre-determined future for most girls in small cities and rural areas.

A few stylized facts about Iran's labor market, household structure, and boys' and girls' job market and marital behavior can help understand the society under investigation in early 1990s. Figure 1 shows that boys were more likely to go to school and to stay longer in school. The difference in schooling between boys and girls in rural areas was much wider than that in urban areas, such that by age 14 more than half of girls in rural areas were out of school. Girls, particularly in rural areas, married earlier than boys. By age 20, about 60 percent of girls in rural areas and more than 40 percent of girls in urban areas were married, compared to 25 percent and 6 percent of boys in rural and urban areas, respectively. Boys and especially girls in rural areas were more likely to work at all ages than boys and girls in urban areas. Boys in rural areas started working as family workers and worked independently as they aged. Girls started as family workers and usually remained as family workers. Boys in urban areas did not start as family workers. They gradually entered the job market and work independently. Girls in urban areas, however, were less likely to work, especially independently. ${ }^{3}$ Such variations provide an excellent ground to investigate fathers' response in labor market to having a daughter or a son.
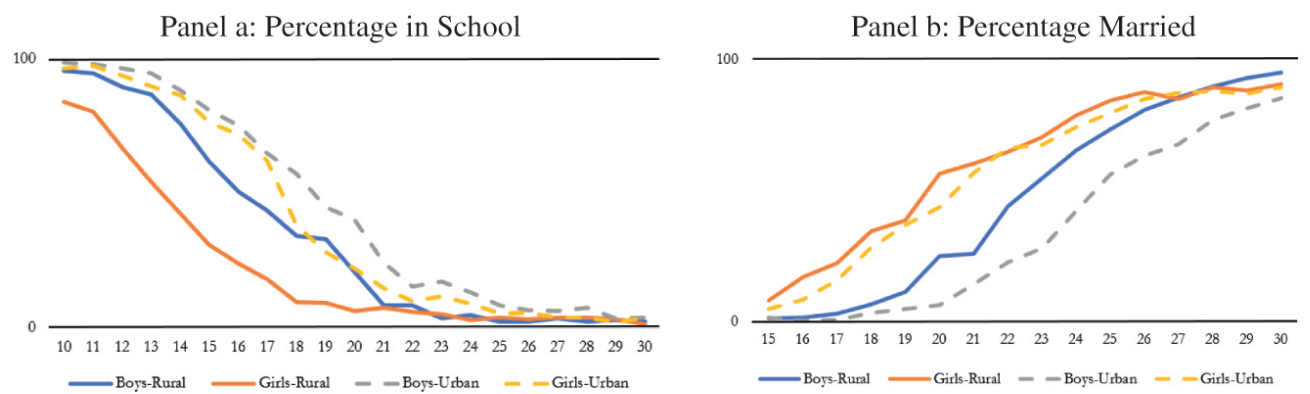

Panel c: Percentage Working

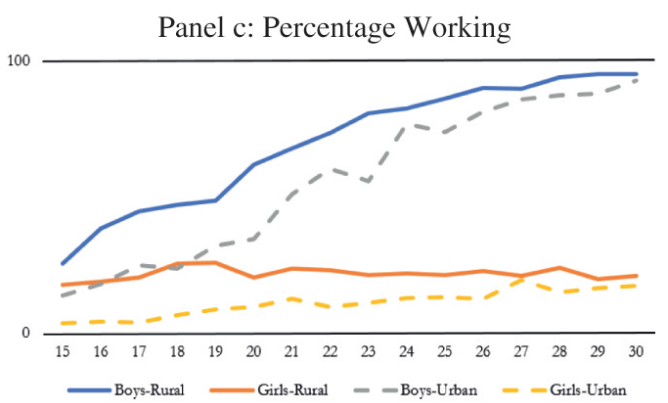

Panel d: Percentage of Workers as Family Workers

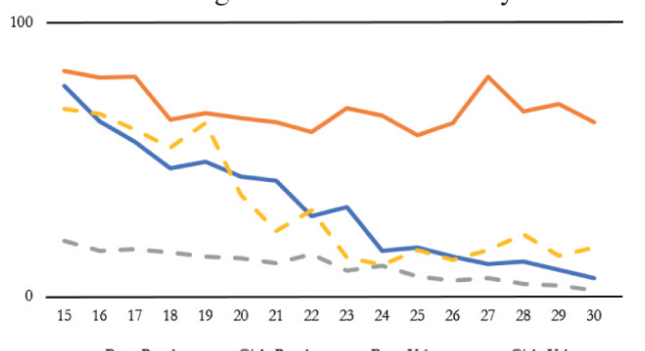

Figure 1: Job market and marital behavior of young boys and girls in urban and rural areas for 1992.

In our main analyses, we use a four-year successive panel survey dataset of households from 1992 to 1995 , which allows us to estimate fixed-effect models to control for time-invariant unobservable factors that may affect a man's labor market outcomes. ${ }^{4}$ We start with measuring the association of having a child with a man's work hours and income. We find that one additional child is associated with about 141 more work hours per year and about 4.5 percent more income. The latter is not statistically significant, but when we consider location and type of income, we find that the effect of parenthood on men's labor patterns are significant and diverse. To measure the effect of children gender on a man's income, the key identifying assumption is the randomness of children's gender at birth. We provide ample evidence from censuses, civil registration, and household budget surveys in rejection of selective abortion in the Iranian context (Appendix B). We find that adding one more female child to a family increases its male head's yearly income by about 4 percent but that adding one more male child has no effect on his income.

We design tests to examine if the heavy financial burden of dowry explains Iranian men's differential responses to their children's gender. First, we find that the effect of having daughters on a man's income increases and becomes more significant as daughters approach the age of marriage, whereas similar effects do not appear for sons. Second, the effects of having daughters on a man's income are stronger, more significant, and emerge earlier in rural areas, where the presence of the dowry tradition is more evident and girls' options outside marriage are more limited. Third, the responsiveness of a man's nonlabor income (which can be considered as the result of his long-term labor market activities) to the gender of his children who are approaching marriage age is stronger than the responsiveness of his labor income (which incurs short-term labor market fluctuations) to the same. Fourth, we rule out the effect of male children's employment and income on their fathers' income. 
This paper is organized as follows. Section two discusses the literature on the role of children's gender on parents' labor patterns and household investments. In Section 3, the data structure is presented, then the rationale behind the identification strategy and choice of econometric models is provided. In Section 4, the results are presented and discussed. In Section 5, additional discussions are provided. Section 6 concludes.

\section{A Review of the Related Literature}

Although the effects of marriage and parenthood on women's labor supply have been extensively studied by economists, the effect of parenthood on men's labor market outcomes have been less frequently studied. Among the traits of the effects on men, children's gender is an important one because of the importance of the implications of any underlying motive. In this regard, two questions arise and intertwine. First, in what ways do men react to their children's gender in the labor market? Second, if any biased behavior is observed, what is its motivation? Suppose that men willingly work more hours when they have sons relative to when they have daughters because they personally prefer to invest in sons over daughters. Then, the gender bias can be indicative of unequal parental treatment of male and female children in terms of education, health, or other family provisions, especially in traditional societies where men are the main breadwinners of families.

Studies that investigate men's labor market responses to their children's gender mainly focus on the first question and tend to find that men intensify their labor market activities following the birth of a male child, relative to when a female child is born. Lundberg and Rose (2002), for example, show that American men work approximately 53 more hours per year if they have at least one son relative to when they have at least one daughter. Furthermore, they show that American men work approximately 69 more hours per year if their first child is a son rather than a daughter. In a similar study, Choi, Joesch, and Lundberg (2008) use data from Germany and report similar behavior.

Lundberg and Rose (2002) and Choi, Joesch, and Lundberg (2008) do not empirically examine the motives behind the documented behavior. The motives are usually explored in studies not concerned with men's labor market activities. One line of such research detects gender bias by investigating the effect of children's gender on family structure, noting that male children increase marital stability and decrease the likelihood of having a second child. ${ }^{5}$ Another line looks at intra-household resource allocation. The latter line of inquiry has derived mixed results from different countries. ${ }^{6}$ Applying the latter methodology to Iranian context, Koohi-Kamali (2011) and Azimi (2014) find evidence of son preference in household resource allocation.

Intra-household resource allocation studies seeks out indications of gender bias at specific levels of income, measured by total expenditures. However, male and female children may differ in terms of childrearing costs, and the difference may induce biased labor market responses to children's gender by men. Some social arrangements, such as dowry, can make children of a certain gender more expensive to raise. In societies where dowry has remained critical to the formation of marital unions, parents who have a female child expect a massive outlay around the time of her marriage, which usually requires savings and purchases in advance. Thus, one can expect that men elevate their labor market activities to finance the associated costs.

Theoretically, a man's labor market reaction to the expectation of provision of a dowry in the future can be explained with an intertemporal consumption-leisure model in which his budget constraints are given by:

$$
\begin{gathered}
c_{1}+s=w_{1} \cdot h_{1} \\
c_{2}+\text { dowry }=w_{2} \cdot h_{2}+(1+r) . s
\end{gathered}
$$

where $c_{1}$ and $c_{2}$ are consumption in the present and future, respectively; $h_{1}$ and $h_{2}$ are hours of work in the present and future; $w_{1}$ and $w_{2}$ are wage rates in the present and future; $s$ is savings; $r$ is the interest rate. Presence of dowry in the second equation requires a combination of adjustments: if the man does not want to change his consumption in comparison to a man with no female child, then he needs to increase his work hours either in the present time $\left(h_{1}\right)$ or in the future $\left(h_{2}\right)$. The choices can be simply characterized by using a log-linear intertemporal utility function and a linear production function. We use men's nonlabor income to examine the effect of child gender on the present time work hours in the intertemporal model, or when the female child is young. We also use men's labor income to examine the effect of child gender on the future time work hours in the model, or when the female child is close to the age of marriage.

Among the studies that have considered the effect of dowry on parents' labor market outcomes, Deolalikar and Rose (1998) use data from rural India, also a dotal society, and show that the birth of a male child relative to that of a female child reduces a household's savings. The decreased savings stem from an increase in the consumption of medicines, cosmetics and soaps, and edible fats and oils. Therefore, the reaction can also be attributed to son favoritism rather than the cancelation of future dowry provisions. In the same context, 
Rose (2000) shows that mothers' working days in both medium and large farm households-that are not expected to face liquidity constraints - and in landless and small farm households - that typically face liquidity constraints - increase in response to the birth of a female child relative to that of a male child in five years after a child's birth. However, fathers in medium and large farm households and in landless and small farm households respond differently to the birth of a female child relative to that of a male child in five years after a child's birth: a positive response is measured for the first but a negative one for the second. The difference of our study with studies of Deolalikar and Rose (1998) and Rose (2000) is that we propose empirical models that are specifically designed to measure the effect of dowry provision on a man's income.

In practice, any empirical analysis that estimates the effect of children's gender on a man's income in a dotal society measures the net effect of two major factors: (1) gender bias against daughters, which can originate from mere son preference or the perception that there are greater returns to a son's human capital, and (2) the higher costs of raising a daughter on account of the financial burden of dowry. Koohi-Kamali (2011) and Azimi (2014) document gender bias in intra-family resource allocations against female children in Iran, which could potentially result in a negative income effect among men with female children. The second factor however is expected to have a positive income effect on men's income. Then, a net positive effect on men's income of having female children can be interpreted as the relative dominance of the cost (dowry) effect over the preference and returns effects. Also, the estimated positive effects can be interpreted as the lower bounds for the labor market effects of dowry.

\section{Data and Econometric Models}

\subsection{Data}

To address potential heterogeneity bias, a panel dataset is best suited to answer the questions of this research. The Iranian panel dataset that is available to us is the 1992-1995 Survey of Household's Socioeconomic Characteristics (SHSC), a four-year panel survey with 172 sampling clusters. The survey started with 5,090 households in 1992 and ended with 3,662 households in 1995, thus bearing a 72 percent retention rate. The survey stopped in 1995 and the households were not followed afterwards. In total, there are 16,978 observation points within the dataset, and 60 percent of households surveyed were urban. This household survey extensively reports in four parts: household members' socioeconomic characteristics, household's belongings and utility access, household expenditures, and household members' income and job. ${ }^{7,8}$

The household member who is interviewed is called the head. ${ }^{9}$ All other household members are coded according to their relationship to the head. We limit our analyses to households in which the head and the head's spouse are present. This criterion reduced our sample to a total of 14,970 observations. Since the intra-family dynamics in single-parent or extended families can be different than that in nuclear families, and the differences can impose unobserved heterogeneities into the estimations, we further restrict the sample to nuclear family households that, in fact, form the vast majority of the entirety of households. In Section 4.2, these restrictions are discussed. Working with all families has a trivial effect on the results and does not change our conclusions.

The data provide several variables that reveal the labor market activities of the surveyed men, including the average number of work hours per day, the average number of work days per week, wage and salary income, self-employment income, and some other miscellaneous forms of income in the past year. We deflate the income values to 1992 prices. Individuals' age, gender, and education are the key variables of interest. For education, we combine two variables (one that contains the literacy status of an individual, and another that contains the individual's education level) and generate an index variable that contains seven values - namely, illiterate, primary education, secondary education, high school education, college education, religious education, and informal education. To proxy a household's wealth, we use the rent equivalent of the household's place of residence. In the context of a developing country, which is generally characterized by limited capital and mortgage markets, the value of a household's dwelling can be considered a household's major source of wealth. ${ }^{10}$

Table 1 reports the summary statistics of the main variables used in this study. For all age groups, the average number of male children is slightly larger than the average number of female children in a household, thus reflecting the natural gender ratio. The difference between the numbers of male and female children in the age groups widens for the older groups, thus reflecting the fact that women marry at younger ages than do men, and hence leave the household sooner. The numbers of male and female children in the 5-9 and 10-14 age groups outnumber those in the other age groups, thus reflecting Iran's high population growth rate in the 1976-1986 period. The subsequent reduction in the growth rate of the population is evident in the smaller numbers of children in the two youngest age groups. As expected, households in rural areas have more children than those 
in urban areas. The difference exists for all age groups, except for those aged 25 years or older, which reflects the lower age of marriage in rural areas.

Table 1: means (standard deviations) of variables

\begin{tabular}{|c|c|c|c|}
\hline & Country & Urban & Rural \\
\hline Logarithm of real total income & $\begin{array}{l}14.77 \\
(0.766)\end{array}$ & $\begin{array}{l}14.80 \\
(0.701)\end{array}$ & $\begin{array}{l}14.25 \\
(0.740)\end{array}$ \\
\hline Weekly hours of work & $\begin{array}{l}46.0 \\
(22.6)\end{array}$ & $\begin{array}{l}45.1 \\
(23.0)\end{array}$ & $\begin{array}{l}47.3 \\
(22.0)\end{array}$ \\
\hline $\begin{array}{l}\text { Monthly rental value of the house if owned } \\
\text { (million Rials) }\end{array}$ & $\begin{array}{l}1.046 \\
(1.547)\end{array}$ & $\begin{array}{l}1.478 \\
(1.831)\end{array}$ & $\begin{array}{l}0.404 \\
(0.526)\end{array}$ \\
\hline Age & $\begin{array}{l}45.67 \\
(14.37)\end{array}$ & $\begin{array}{l}45.20 \\
(13.75)\end{array}$ & $\begin{array}{l}46.38 \\
(15.21)\end{array}$ \\
\hline Number of children & $\begin{array}{l}3.28 \\
(2.15)\end{array}$ & $\begin{array}{l}3.04 \\
(1.94)\end{array}$ & $\begin{array}{l}3.63 \\
(2.38)\end{array}$ \\
\hline Number of boys & $\begin{array}{l}1.79 \\
(1.45)\end{array}$ & $\begin{array}{l}1.66 \\
(1.35)\end{array}$ & $\begin{array}{l}1.97 \\
(1.66)\end{array}$ \\
\hline Number of girls & $\begin{array}{l}1.49 \\
(1.37)\end{array}$ & $\begin{array}{l}1.37 \\
(1.28)\end{array}$ & $\begin{array}{l}1.67 \\
(1.48)\end{array}$ \\
\hline Number of boys in age range $0-4$ & $\begin{array}{l}0.30 \\
(0.54)\end{array}$ & $\begin{array}{l}0.25 \\
(0.49)\end{array}$ & $\begin{array}{l}0.38 \\
(0.61)\end{array}$ \\
\hline Number of girls in age range $0-4$ & $\begin{array}{l}0.29 \\
(0.54)\end{array}$ & $\begin{array}{l}0.23 \\
(0.48)\end{array}$ & $\begin{array}{l}0.36 \\
(0.60)\end{array}$ \\
\hline Number of boys in age range 5-9 & $\begin{array}{l}0.43 \\
(0.65)\end{array}$ & $\begin{array}{l}0.40 \\
(0.62)\end{array}$ & $\begin{array}{l}0.48 \\
(0.70)\end{array}$ \\
\hline Number of girls in age range 5-9 & $\begin{array}{l}0.42 \\
(0.65)\end{array}$ & $\begin{array}{l}0.38 \\
(0.62)\end{array}$ & $\begin{array}{l}0.46 \\
(0.69)\end{array}$ \\
\hline Number of boys in age range $10-14$ & $\begin{array}{l}0.44 \\
(0.68)\end{array}$ & $\begin{array}{l}0.41 \\
(0.63)\end{array}$ & $\begin{array}{l}0.50 \\
(0.71)\end{array}$ \\
\hline Number of girls in age range $10-14$ & $\begin{array}{l}0.40 \\
(0.65)\end{array}$ & $\begin{array}{l}0.38 \\
(0.64)\end{array}$ & $\begin{array}{l}0.42 \\
(0.68)\end{array}$ \\
\hline Number of boys in age range 15-19 & $\begin{array}{l}0.32 \\
(0.60)\end{array}$ & $\begin{array}{l}0.30 \\
(0.59)\end{array}$ & $\begin{array}{l}0.34 \\
(0.61)\end{array}$ \\
\hline Number of girls in age range $15-19$ & $\begin{array}{l}0.25 \\
(0.52)\end{array}$ & $\begin{array}{l}0.23 \\
(0.49)\end{array}$ & $\begin{array}{l}0.28 \\
(0.55)\end{array}$ \\
\hline Number of boys in age range $20-24$ & $\begin{array}{l}0.19 \\
(0.47)\end{array}$ & $\begin{array}{l}0.18 \\
(0.45)\end{array}$ & $\begin{array}{l}0.21 \\
(0.48)\end{array}$ \\
\hline Number of girls in age range $20-24$ & $\begin{array}{l}0.10 \\
(0.34)\end{array}$ & $\begin{array}{l}0.09 \\
(0.32)\end{array}$ & $\begin{array}{l}0.12 \\
(0.36)\end{array}$ \\
\hline Number of boys in age 25 and over & $\begin{array}{l}0.10 \\
(0.36)\end{array}$ & $\begin{array}{l}0.12 \\
(0.39)\end{array}$ & $\begin{array}{l}0.08 \\
(0.29)\end{array}$ \\
\hline Number of girls in age 25 and over & $\begin{array}{l}0.04 \\
(0.23)\end{array}$ & $\begin{array}{l}0.05 \\
(0.24)\end{array}$ & $\begin{array}{l}0.03 \\
(0.20)\end{array}$ \\
\hline Number of Observations & 14,970 & 8,958 & 6,012 \\
\hline
\end{tabular}

Notes: For some variables, the number of observations are less than indicated in table due to missing observations. The values of the variables Real Total Income and Monthly Rental Value of Owned Residence are logarithms of the corresponding values in the Iranian currency. Standard errors are in parentheses. Data Source: Survey of Household's Socioeconomic Characteristics (SHSC), Statistical Center of Iran (SCI).

\subsection{Identification Strategy and Econometric Models}

We consider both ordinary least squares (OLS) and individual-level fixed-effects models. Though, OLS models suffer from heterogeneity bias originated from unobserved ability in the labor market, ${ }^{11}$ they can provide preliminary evidence for the theory. Presenting OLS results alongside the fixed-effect results also proves the existence of heterogeneity bias. In addition, it provides evidence in support of choosing fixed-effects versus random effects model. The use of fixed-effects model is further confirmed by Hausman tests.

In our preferred model (the fixed-effect model), the main identification assumption is the randomness of children's gender. Testing for selective abortion illustrates the strength of this assumption. In Appendix B, we test for the use of selective abortion by checking the male-female ratios at different age groups and show that there is no evidence of gender selection in Iran. 
We estimate two sets of equations. First, we use two specifications to measure the effect of having children, regardless of their gender, on a man's income and work hours. The two specifications are:

$$
\begin{aligned}
& Y_{i t}=\alpha+\beta \cdot C H I L D_{i t}+\gamma_{1} \cdot M A G E_{i t}+\gamma_{2} \cdot M A G E_{i t}^{2}+\delta_{1} \cdot M E D U_{i t}+\delta_{2} \cdot W_{E D U}+ \\
& \omega . H W E A L T H_{i t}+\theta \cdot C H I L D E M P_{i t}+\mu . U R B A N_{i t}+u_{i t} \\
& Y_{i t}=\alpha+\sum_{5}^{j=1} \beta_{j} \cdot C H I L D j_{i t}+\gamma_{1} \cdot M A G E_{i t}+\gamma_{2} \cdot M A G E_{i t}^{2}+\delta_{1} \cdot M E D U_{i t}+\delta_{2} \cdot W E D U_{i t}+ \\
& \omega . H W E A L T H_{i t}+\theta \cdot C H I L D E M P_{i t}+\mu . U R B A N_{i t}+u_{i t}
\end{aligned}
$$

where subscript $i$ indicates a man or a father and $t$ indicates time. Variable $Y$ is the man's labor market outcome: average weekly hour of work or the logarithm of real total income. In eq. 1], the variable of interest is a dummy that indicates having children, CHILD. In eq. 2], the general indicator is broken two CHILD1, CHILD2, CHILD3, CHILD4, and CHILD5 - which are dummy variables for having one, two, three, four, and more than four children, respectively - to examine the effect on labor market outcomes of the presence of different number of children. MAGE is the man's age, MAGE'2 is the square of his age, ${ }^{12}$ and MECU indicates his education level. WECU indicates his wife's education level, HWEALTH is a variable that proxies the household's wealth by using the value of its residence, CHILDEMP is a set of variables that indicate the employment status of the man's male and female children, and URBAN indicates if the household is living in urban or rural areas. The coefficient of interest in eq. 1 is $\beta$, while $\beta_{j}$ 's are the coefficients of interest in eq. 2].

The focus of this study is to measure the effect of children's gender on men's income. Thus, the second set of equations are designed to measure the effect of the children's gender on the man's income:

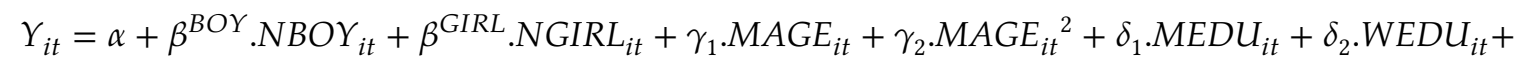

$$
\begin{aligned}
& \omega . H W E A L T H_{i t}+\theta \cdot C H I L D E M P_{i t}+\mu . U R B A N_{i t}+u_{i t}
\end{aligned}
$$

$$
\begin{aligned}
& Y_{i t}=\alpha+\sum_{k} \beta_{k}^{B O Y} \cdot{ }^{N B O Y} Y_{k, i t}+\sum_{k} b e t a_{k}^{G I R L} \cdot N G I R L_{k, i t}+\gamma_{1} \cdot M A G E_{i t}+\gamma_{2} \cdot M A G E_{i t}^{2}+\delta_{1} \cdot M_{E D U}+\delta 2 \cdot W E D U_{i t}+ \\
& \omega \cdot H W E A L T H_{i t}+\theta \cdot C H I L D E M P_{i t}+\mu \cdot U R B A N_{i t}+u_{i t}
\end{aligned}
$$

where subscript $i$ indicates a man, $k$ indicates the age group of his male or female children, and $t$ shows time. The man's real income is shown by $Y$. In eq. 3], the variables of interest are NBOY and NGIRL, which represent the man's numbers of male and female children, respectively. They also captures the effect of children's gender. Therefore, the coefficients of interest in eq. 3 are $\beta^{B O Y}$ and $\beta^{G I R L}$. In eq. 4], the man's male and female children are distributed into age groups, such that $N B O Y_{k, i t}$ and $N G I R L_{k, i t}$ represent the numbers of male and female children who are at age group $k$, respectively. The selected age groups are 0-4, 5-9, 10-14, 15-19, and 20-24 years. In effect, we include the following variables in the specification: $N B O Y_{0-4, i t}, N B O Y_{5-9, i t}, N B O Y_{10-14, i t}$,

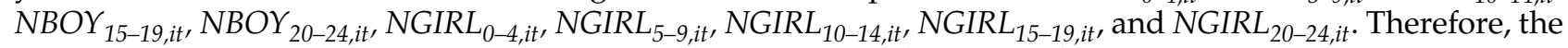

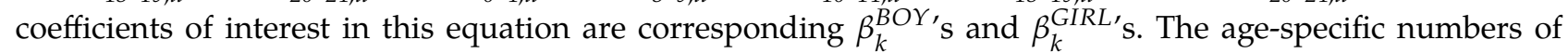
boys and girls are defined to understand the effect of dowry, which it is not directly measured. If dowry is crucial, then we should expect men to invest differently as daughters approach marriage age. ${ }^{13}$ To strengthen the argument that dowry can explain men's differential responses to their children's gender, we also estimate eqs 3 and 4 for urban and rural areas separately.

Controlling for the employment status of male and female children is especially important in eqs 3 and 4], because male and female children's differences in terms of employment status - which can lead to their differential financial contributions to the household - may impact a man's response to the gender of his children. Therefore, to isolate the effects of interest - namely, the effects of children's gender by their age - we also include children's employment status among the explanatory variables.

The outcome variable of interest, a man's total income, is the summation of his wages and salaries, selfemployment income, and miscellaneous forms of income. Total income then reflects the results of all of his activities to provide for his family. The key attribute of this variable is that it incorporates both short-term and long-term elements of the man's labor market activities. While wage and salary and self-employment income subsume the accumulative results of the man's lifetime labor market efforts, they are also influenced by labor market fluctuations in the calendar year prior to the date of interview. However, the miscellaneous forms of income - which include income from pensions, renting real estate properties, renting non-real estate properties, interest on liquid assets, insurance compensations, and selling handicrafts, inter alia - show to a great extent the results of a man's long-term efforts and investments and are less influenced by short-term fluctuations. ${ }^{14}$ 


\section{Results}

\subsection{The Effects of Having Children on Fathers' Work Hours and Income}

We start our analyses by investigating the effects of parenthood on men's work hours and income. Table 2 presents the results of the estimations of eqs 1 and 2], with men's average weekly work hours in the past year as the dependent variable. ${ }^{15}$ Columns (1) and (2) contain the OLS estimates, and columns (3) and (4) present the fixed-effect estimates. Furthermore, columns (1) and (3) present the basic models in which the total number of children is included, whereas columns (2) and (4) contain nonlinear specifications that use dummy variables for one, two, three, four, and more than four children. In all of the estimations, we control for the education level of the men and of their wives, the men's age, the square of the men's age, the rental value of the place of residence as a wealth indicator, and children's employment status. Urban/rural and province weights are applied to observations, and standard errors are calculated by clustering the data per sampled cluster. ${ }^{16}$ Furthermore, the table shows the chi-squared values of the Hausman test of selecting between fixed effects against random effects model.

Table 2: The effect of having children on a man's average weekly work hours.

\begin{tabular}{lllll}
\hline & $\mathbf{( 1 )}$ & $\mathbf{( 2 )}$ & $\mathbf{( 3 )}$ & $\mathbf{( 4 )}$ \\
& OLS & OLS & FE & FE \\
\hline Any children (Dummy: 0 if none) & $1.690^{* *}$ & & $2.718^{*}$ & \\
& $(0.801)$ & & $(2.420)$ & \\
Exactly one child & & 0.705 & & $2.796^{*}$ \\
& & $(0.875)$ & & $(1.505)$ \\
Exactly two children & & 1.159 & & 2.379 \\
Exactly three children & & $(0.887)$ & & $(1.579)$ \\
Exactly four children & & $1.834^{* * *}$ & & $(1.811$ \\
& & $(0.916)$ & & $3.243^{*}$ \\
More than four children & $2.278^{* * *}$ & & $(1.890)$ \\
& & $(0.959)$ & $4.561^{* *}$ \\
Number of observations & $3.482^{* * *}$ & & $(1.894)$ \\
Chi-square of Hausman Test & & $(0.949)$ & & 14,960 \\
\hline
\end{tabular}

Notes: OLS and FE indicate ordinary least squares and fixed-effect regressions, respectively. Control variables are men's and their wives levels of education, men's age, the square of men's age, and a wealth indicator. Urban/rural and province weights are applied. Standard errors clustered per sampling cluster are in parentheses. ${ }^{* * * *}, * * *$ indicate significance at $1 \%, 5 \%$, and $10 \%$ levels, respectively.

The results of Hausman test is based on fixed effects model and random effects model (not reported here) with regular standard errors and without using weight.

Data Source: Survey of Household's Socioeconomic Characteristics (SHSC), Statistical Center of Iran (SCI).

The basic OLS results show that having children is associated with working more hours. The effects are significant when using as regressors either the total number of children or dummy variables for different numbers of children. Furthermore, the effects strengthen and become more significant as the number of children increases. In addressing possible heterogeneity biases, the fixed-effect models show that the results hold even after controlling for individual-level unobservable factors. The fixed-effect estimation in column (3) shows that a man with children works about 2 hours and 43 minutes more per week than a man with no child - that is, 141 additional hours per year. The effect varies, depending upon the number of children. The first child has a significant effect and adds 2 hours and 48 minutes to a man's weekly work hours ( $145 \mathrm{~h}$ per year). In comparison, Lundberg and Rose (2002) find that the first child adds about 82 hours to an American man's annual hours of work. In Germany, the effect is about 56 hours (Choi, Joesch, and Lundberg 2008). The second and third children have smaller and less significant effects, but the effect becomes larger and more significant after the third child. A man with more than four children works approximately five additional hours per week, or 237 hours per year, than a man with no child. Hausman test results confirm the existence of non-random heterogeneity. Chi-square values are very large, 85 and 82 for two models, and we can confidently reject the null hypothesis of two models being statistically the same.

Table 3 presents the results of estimating eqs 1 and 2 with the logarithm of men's total income as the dependent variable; the results therein suggest that the effect of children on men's total income is similar to that on their weekly work hours. The OLS estimates in column (1) show that a man with children earns approximately 20 percent more than a man with no child. Most of these differences can be ascribed to unobservable 
factors; thus, the fixed-effect estimates presented in column (3) show that only approximately 4.5 percent of these differences can be attributed to the child effect. The measured effect is comparable to those measured by Lundberg and Rose (2002) and Choi, Joesch, and Lundberg (2008) in the U.S. and Germany, respectively. Lundberg and Rose (2002) find that a child increases an American man's earning by about 4.2 percent. Choi et al.'s (2008) measurement of the same effect in Germany is about 4.8 percent.

Table 3: The effect of having children on a man's log total income.

\begin{tabular}{|c|c|c|c|c|}
\hline & $\begin{array}{l}\text { (1) } \\
\text { OLS }\end{array}$ & $\begin{array}{l}\text { (2) } \\
\text { OLS }\end{array}$ & $\begin{array}{l}\text { (3) } \\
\text { FE }\end{array}$ & $\begin{array}{l}\text { (4) } \\
\text { FE }\end{array}$ \\
\hline Any children & $\begin{array}{l}0.197^{* * *} \\
(0.027)\end{array}$ & & $\begin{array}{l}0.045 \\
(0.056)\end{array}$ & \\
\hline Exactly one child & & $\begin{array}{l}0.111^{* * *} \\
(0.028)\end{array}$ & & $\begin{array}{l}0.036 \\
(0.056)\end{array}$ \\
\hline Exactly two children & & $\begin{array}{l}0.166^{* * *} \\
(0.028)\end{array}$ & & $\begin{array}{l}0.055 \\
(0.063)\end{array}$ \\
\hline Exactly three children & & $\begin{array}{l}0.216^{* * *} \\
(0.030)\end{array}$ & & $\begin{array}{l}0.092 \\
(0.062)\end{array}$ \\
\hline Exactly four children & & $\begin{array}{l}0.231^{* * *} \\
(0.032)\end{array}$ & & $\begin{array}{l}0.089 \\
(0.072)\end{array}$ \\
\hline More than four children & & $\begin{array}{l}0.325^{* * *} \\
(0.032)\end{array}$ & & $\begin{array}{l}0.152^{*} \\
(0.074)\end{array}$ \\
\hline $\begin{array}{l}\text { Number of observations } \\
\text { Chi-square of Hausman Test }\end{array}$ & 13,981 & 13,981 & $\begin{array}{l}13,981 \\
142.3^{* * *}\end{array}$ & $\begin{array}{l}13,981 \\
152.89^{* * * *}\end{array}$ \\
\hline
\end{tabular}

Notes: OLS and FE indicate ordinary least squares and fixed-effect regressions, respectively. Control variables are men's and their wives levels of education, men's age, the square of men's age, and a wealth indicator. Urban/rural and province weights are applied. Standard errors clustered per sampling cluster are in parentheses. ${ }^{* * *}, * * *$ indicate significance at $1 \%, 5 \%$, and $10 \%$ levels, respectively.

The results of Hausman test is based on fixed effects model and random effects model (not reported here) with regular standard errors and without using weight.

Data Source: Survey of Household's Socioeconomic Characteristics (SHSC), Statistical Center of Iran (SCI).

The effect of having children on men's income follows the same trend as that on work hours: the number of children correlates positively with income. Moreover, the largest and most significant effects are seen among fathers with more than four children. Our analysis shows that a man with more than four children earns approximately 32.5 percent more in comparison to a man with no child. Even after controlling for time invariant unobservable factors, the effect remains high (about 15 percent) and significant. In this case, also the result of Hausman tests strongly support the idea that fixed effects model is proper model to use.

The finding that having numerous children is associated with a man's higher level of labor market activity contrasts with the findings of Lundberg and Rose (2002) about US men, but it is generally consistent with the context of developing countries where both positive and negative relationships between household size and household wealth are measured (Maralani 2008). In the Iranian context, a possible influence of the institution of marriage, as discussed in the next section - provides one explanation for the increase in work hours and hence in income in the presence of multiple children.

\subsection{The Effects of Children's Gender on Men's Income}

This section presents and discusses the main findings of this study. The effects of children's gender on men's total income and the possible role of a dotal society's marriage institutions in shaping these effects are investigated by estimating eqs 3 and 4], where individual-level fixed-effect factors are accounted for and the logarithm of men's real total income is used as the dependent variable. ${ }^{17}$

Using women's birth history, we identify families inside households. To eliminate potential unobserved heterogeneities in the sample, we impose several restrictions on the regressions. First, we exclude households that include families with no child. Second, we exclude households that contain families that have married children who are either living in the household with their spouses, or outside of it. ${ }^{18}$ Among the remaining households, we retain those containing no members other than parents and their own present children, because grandparents, the male head's brothers and sisters, or the female head's brothers and sisters may share the financial burden of the household and, thus, distort our analyses.

The effects of children's gender on a man's total income are presented in Table 4. The effects of a total number of male and female children on a man's total income are derived from estimating eq. 3]; the results are presented 
in column (1). The age-specific effects of the number of male and female children on the man's total income are derived from estimating eq. 4]; these results are presented in column (2). In all the estimations, we control for the education levels of the men and their wives, men's age, the square of men's age, the rental value of the place of residence as a wealth indicator, and the employment status of male and female children. Urban/rural and province weights are applied to observations and standard errors are calculated by clustering the data per sampling cluster.

Table 4: The effect of children's gender on a man's log total income.

\begin{tabular}{|c|c|c|}
\hline & (1) & (2) \\
\hline Number of boys & $\begin{array}{l}-0.008 \\
(0.021)\end{array}$ & \\
\hline Number of girls & $\begin{array}{l}0.036^{*} \\
(0.020)\end{array}$ & \\
\hline $\begin{array}{l}\text { Difference in coefficients (Girls-Boys) } \\
\text { [p-value for Difference>0] }\end{array}$ & $\begin{array}{l}0.044 \\
{[p=0.044]}\end{array}$ & \\
\hline Number of boys $0-4$ years old & & $\begin{array}{l}-0.012 \\
(0.025)\end{array}$ \\
\hline Number of girls $0-4$ years old & & $\begin{array}{l}0.007 \\
(0.025)\end{array}$ \\
\hline $\begin{array}{l}\text { Difference in coefficients (Girls-Boys) } \\
\text { [p-value for Difference>0] }\end{array}$ & & $\begin{array}{l}0.019 \\
{[p=0.267]}\end{array}$ \\
\hline Number of boys $5-9$ years old & & $\begin{array}{l}0.006 \\
(0.029)\end{array}$ \\
\hline Number of girls $5-9$ years old & & $\begin{array}{l}0.036 \\
(0.024)\end{array}$ \\
\hline $\begin{array}{l}\text { Difference in coefficients (Girls-Boys) } \\
\text { [p-value for Difference >0] }\end{array}$ & & $\begin{array}{l}0.030 \\
{[p=0.135]}\end{array}$ \\
\hline Number of boys $10-14$ years old & & $\begin{array}{l}0.010 \\
(0.029)\end{array}$ \\
\hline Number of girls $10-14$ years old & & $\begin{array}{l}0.054^{*} \\
(0.028)\end{array}$ \\
\hline $\begin{array}{l}\text { Difference in coefficients (Girls-Boys) } \\
\text { [p-value for Difference>0] }\end{array}$ & & $\begin{array}{l}0.044 \\
{[p=0.101]}\end{array}$ \\
\hline Number of boys $15-19$ years old & & $\begin{array}{l}-0.028 \\
(0.029)\end{array}$ \\
\hline Number of girls 15-19 years old & & $\begin{array}{l}0.052^{*} \\
(0.027)\end{array}$ \\
\hline $\begin{array}{l}\text { Difference in coefficients (Girls-Boys) } \\
\text { [p-value for Difference>0] }\end{array}$ & & $\begin{array}{l}0.080 \\
{[p=0.023]}\end{array}$ \\
\hline Number of boys $20-24$ years old & & $\begin{array}{l}-0.018 \\
(0.034)\end{array}$ \\
\hline Number of girls 20-24 years old & & $\begin{array}{l}0.092^{* * * *} \\
(0.033)\end{array}$ \\
\hline $\begin{array}{l}\text { Difference in coefficients (Girls-Boys) } \\
\text { [p-value for Difference>0] }\end{array}$ & & $\begin{array}{l}0.110 \\
{[p=0.006]}\end{array}$ \\
\hline Number of observations & 9,895 & 9,895 \\
\hline
\end{tabular}

Notes: Both columns (1) and (2) show the results of estimating fixed-effect models. Control variables are men's and their wives levels of education, men's age, the square of men's age, wealth indicator, and children's employment status. Urban/rural and province weights are applied. Standard errors clustered per sampling cluster are in parentheses. ${ }^{* * *}, * * *$, indicate significance at $1 \%, 5 \%$, and $10 \%$ levels, respectively.

Data Source: Survey of Household's Socioeconomic Characteristics (SHSC), Statistical Center of Iran (SCI).

The results in Table 4 show that a man with female children on average generates about 3.6 percent more income than a man with male children. The size of the measured differential effect is comparable to that measured by Lundberg and Rose (2002), which is about 3 percent in the American men born before 1950, although the sign of the effect is opposite to theirs. The sign of our measured effect however is consistent with that of Deolalikar and Rose (1998) who study the effect on household savings of a child birth in rural India. Choi, Joesch, and Lundberg (2008), on the other hand, measure no differential effect of children gender on German fathers' earnings.

The differential effect of having a female child versus having a male child, which is also statistically significant, is approximately 4 percent, on average (column 1). More importantly, the reported effects in column (2) show that the female child versus male child differential effect on total income of the man increases by child age. Specifically, having a 0-4 years old daughter does not have a significant effect on the man's total income, 
but having a 5-9, 10-14, 15-19, or 20-14 years old daughter increases the man's income by approximately 3.6, $5.4,5.2$, and 9.2 percent, respectively. The effects of having male children are not significant across any of the age groups. Additionally, the tests indicate that the coefficients for female children are significantly greater than those for male children, and the differences widen and increase with age.

The pattern in the age-specific effects suggests a mechanism for the impact of children's gender on men's income. The institution of dowry can be suspected as the underlying mechanism since the female-versus-male children differential effect increases as children approach the age of marriage. In fact, the financial burden of dowry is so substantial in comparison to a typical family's regular expenditures, a family cannot simply and temporarily reduce its expenses to provide it; instead, the family must prepare for a long-term saving and storing plan. ${ }^{19}$ A typical Iranian man's adjustments of his life-time labor market activities in response to the expectation of the large financial outlay after the birth of a female child is consistent with the theoretical frameworks that models intertemporal labor decisions. In the next, we provide further evidence in support of the dowry effect.

\section{Discussion}

In Section 4, we found that having female children rather than male children has a positive effect on a man's income. We interpreted the age-specific pattern of the results as evidence of the impact of the marriage institution of dowry. In this section, we offer further evidence in support of a dowry effect by examining it in rural and urban areas, and in terms of labor and nonlabor income. In deriving the effects, we also rule out prominent alternative explanations for the dowry effect, i. e., the role of male children's employment and income. Finally, we present the results of a series of robustness tests.

\subsection{Testing the Dowry Effect in Rural and Urban Areas}

Investigating urban and rural men's differential responses to their children's gender sheds more light on the underlying mechanism of the effect of children's gender on men's income. A stronger effect is expected in rural areas where the tradition of dowry is more important in socioeconomic lives. Table 5 presents the genderand age-specific effects of children on the total income of a rural man versus an urban man, derived from the fixed-effect estimations of eq. 4]. The results show an overall trend, i. e., the association between older female children and higher total income, in both urban and rural areas, but the effects in rural areas are stronger and more significant. More importantly, the effect of having female children on a father's total income appears earlier in rural areas: the effect is stronger and more significant, even with female children as young as 5-9 years old. This reflects the fact shown in Table 1, panel b, that girls marry at younger ages in rural areas.

Table 5: The Effect of children's gender on a man's log total income in urban and rural areas.

\begin{tabular}{lll}
\hline & Urban & Rural \\
\hline Number of boys 0-4 years old & 0.023 & -0.034 \\
& $(0.034)$ & $(0.032)$ \\
Number of girls 0-4 years old & 0.004 & 0.022 \\
& $(0.036)$ & $(0.034)$ \\
Difference in coefficients (Girls-Boys) & -0.019 & 0.056 \\
[p-value for Difference $>0$ ] & {$[\mathrm{p}=0.687]$} & {$[\mathrm{p}=0.101]$} \\
Number of boys 5-9 years old & 0.048 & -0.030 \\
& $(0.047)$ & $(0.026)$ \\
Number of girls 5-9 years old & 0.012 & $0.060^{* * *}$ \\
& $(0.043)$ & $(0.022)$ \\
Difference in coefficients (Girls-Boys) & -0.036 & 0.090 \\
[p-value for Difference>0] & {$[\mathrm{p}=0.871]$} & {$[\mathrm{p}=0.003]$} \\
Number of boys 10-14 years old & 0.050 & -0.023 \\
& $(0.040)$ & $(0.036)$ \\
Number of girls 10-14 years old & 0.0560 & 0.049 \\
& $(0.045)$ & $(0.036)$ \\
Difference in coefficients (Girls-Boys) & 0.006 & 0.072 \\
[p-value for Difference $>0]$ & {$[\mathrm{p}=0.430]$} & {$[\mathrm{p}=0.084]$} \\
Number of boys 15-19 years old & -0.003 & -0.034 \\
& $(0.0409)$ & $(0.039)$
\end{tabular}




$\begin{array}{lll}\text { Number of girls 15-19 years old } & 0.046 & 0.069^{*} \\ & (0.038) & (0.039) \\ \text { Difference in coefficients (Girls-Boys) } & 0.049 & 0.103 \\ \text { [p-value for Difference>0] } & {[\mathrm{p}=0.125]} & {[\mathrm{p}=0.050]} \\ \text { Number of boys 20-24 years old } & 0.045 & -0.056 \\ & (0.042) & (0.052) \\ \text { Number of girls 20-24 years old } & 0.097^{* *} & 0.088^{*} \\ & (0.048) & (0.046) \\ \text { Difference in coefficients (Girls-Boys) } & 0.052 & 0.144 \\ \text { [p-value for Difference }>0 \text { ] } & {[\mathrm{p}=0.149]} & {[\mathrm{p}=0.001]} \\ \text { Obs. } & 5,915 & 3,980\end{array}$

Notes: Both urban and rural estimates are derived from fixed-effect models. Control variables are men's and their wives levels of education, men's age, the square of men's age, wealth indicator, and children's employment status. Urban/rural and province weights are applied. Standard errors clustered per sampling cluster are in parentheses. ${ }^{* * * * * * *},{ }^{*}$ indicate significance at $1 \%, 5 \%$, and $10 \%$ levels, respectively.

Data Source: Survey of Household's Socioeconomic Characteristics (SHSC), Statistical Center of Iran (SCI).

\subsection{Testing the Dowry Effect on Labor and Nonlabor Incomes}

In this section, instead of working with total income, we break down a man's total income into labor and nonlabor incomes and examine their responsiveness to children's gender. We define "labor income" as income that derives from wage-based and salaried jobs, self-employed jobs, or the selling of handicrafts. "Nonlabor income" then includes income from other sources, such as pensions, renting real estate properties, renting non-real estate properties, interests from liquid assets, and insurance compensations.

The importance of analyzing labor and nonlabor income lies in the fact that preparations to afford a dowry need to be made long before a female child reaches the age of marriage, given its immense cost in comparison to the total regular expenditures of the average household (Appendix A). This breakdown allows for distinguishing between two effectsof children's gender on: (1) non-labor income, which is part of a man's income that reflects his long-term labor market activities; and, (2) labor income, which is influenced by temporary labor market fluctuations or more recent intra-family shocks. Such income categorization is relevant to the Iranian society that has undergone high rates of inflation in the last three decades and have therefore mainly resorted to real estate purchases to secure the value of their savings. ${ }^{20}$ This tendency is seen in the data, wherein a man's income from renting real estate properties, on average, constitutes about 65 percent of all his nonlabor income and about 40 percent of his total income in the estimation sample.

Table 6 presents the gender- and age-specific effects of children on an average man's labor and nonlabor income in the nation, in urban areas, and in rural areas. At the country-level, the results - which were derived from the fixed-effect estimations of eq. 4] - present a revealing pattern. First, the presence of young children has a positive and statistically significant effect on a man's labor and nonlabor income. Second, the differential effects of having female versus male children on both labor and nonlabor income are generally positive across all the age groups. Third, nonlabor income is more responsive to children's gender, especially when children are female and approaching the age of marriage. In fact, the greatest positive and statistically significant effect on a man's nonlabor income is seen when the man has female children who are most likely to marry, i.e., 20-24 age group, that effect translates into an income increase of about 12 percent.

Table 6: The Effect of children's gender on a man's log labor and nonlabor income in urban and rural areas

\begin{tabular}{|c|c|c|c|c|c|c|}
\hline & $\begin{array}{l}\text { Country } \\
\text { Labor }\end{array}$ & Nonlabor & $\begin{array}{l}\text { Urban } \\
\text { Labor }\end{array}$ & Nonlabor & $\begin{array}{l}\text { Rural } \\
\text { Labor }\end{array}$ & Nonlabor \\
\hline $\begin{array}{l}\text { Number of boys } 0-4 \text { years old } \\
(0.029)\end{array}$ & $\begin{array}{l}0.048^{*} \\
(0.064)\end{array}$ & $\begin{array}{l}0.059 \\
(0.039)\end{array}$ & $\begin{array}{l}0.104^{* * *} \\
(0.050)\end{array}$ & $\begin{array}{l}0.120^{* *} \\
(0.039)\end{array}$ & $\begin{array}{l}0.005 \\
(0.104)\end{array}$ & -0.035 \\
\hline $\begin{array}{l}\text { Number of girls } 0-4 \text { years old } \\
(0.034)\end{array}$ & $\begin{array}{l}0.054^{*} \\
(0.054)\end{array}$ & $\begin{array}{l}0.111^{* *} \\
(0.039)\end{array}$ & $\begin{array}{l}0.089^{* *} \\
(0.044)\end{array}$ & $\begin{array}{l}0.135^{* * *} \\
(0.048)\end{array}$ & $\begin{array}{l}0.032 \\
(0.095)\end{array}$ & 0.085 \\
\hline $\begin{array}{l}\text { Difference in coefficients } \\
\text { (Girls-Boys) }\end{array}$ & 0.006 & 0.052 & -0.015 & 0.015 & 0.027 & 0.120 \\
\hline [p-value for Difference $>0$ ] & {$[\mathrm{p}=0.430]$} & {$[\mathrm{p}=0.146]$} & {$[\mathrm{p}=0.635]$} & {$[\mathrm{p}=0.381]$} & {$[\mathrm{p}=0.302]$} & {$[\mathrm{p}=0.085]$} \\
\hline $\begin{array}{l}\text { Number of boys } 5-9 \text { years old } \\
(0.027)\end{array}$ & $\begin{array}{l}0.056^{* *} \\
(0.059)\end{array}$ & $\begin{array}{l}0.043 \\
(0.047)\end{array}$ & $\begin{array}{l}0.133^{* * *} \\
(0.043)\end{array}$ & $\begin{array}{l}0.063 \\
(0.027)\end{array}$ & $\begin{array}{l}-0.023 \\
(0.098)\end{array}$ & -0.001 \\
\hline $\begin{array}{l}\text { Number of girls } 5-9 \text { years old } \\
(0.027)\end{array}$ & $\begin{array}{l}0.068^{* *} \\
(0.049)\end{array}$ & $\begin{array}{l}0.069 \\
(0.037)\end{array}$ & $\begin{array}{l}0.083^{* *} \\
(0.047)\end{array}$ & $\begin{array}{l}0.054 \\
(0.036)\end{array}$ & $\begin{array}{l}0.043 \\
(0.089)\end{array}$ & 0.061 \\
\hline Difference in coefficients & 0.012 & 0.026 & -0.050 & -0.009 & 0.066 & 0.062 \\
\hline
\end{tabular}

(Girls-Boys) 


\begin{tabular}{|c|c|c|c|c|c|c|}
\hline [p-value for Difference $>0$ ] & {$[\mathrm{p}=0.336]$} & {$[\mathrm{p}=0.297]$} & {$[\mathrm{p}=0.917]$} & {$[\mathrm{p}=0.565]$} & {$[\mathrm{p}=0.040]$} & {$[\mathrm{p}=0.225]$} \\
\hline $\begin{array}{l}\text { Number of boys } 10-14 \text { years } \\
\text { old }\end{array}$ & 0.007 & 0.046 & 0.067 & 0.025 & -0.045 & 0.087 \\
\hline$(0.027)$ & $(0.053)$ & $(0.043)$ & $(0.043)$ & $(0.033)$ & $(0.087)$ & \\
\hline $\begin{array}{l}\text { Number of girls } 10-14 \text { years } \\
\text { old }\end{array}$ & 0.044 & 0.045 & 0.054 & 0.023 & 0.029 & 0.055 \\
\hline$(0.033)$ & $(0.055)$ & $(0.045)$ & $(0.046)$ & $(0.044)$ & $(0.098)$ & \\
\hline $\begin{array}{l}\text { Difference in coefficients } \\
\text { (Girls-Boys)p-value for } \\
\text { Difference }>0\end{array}$ & 0.037 & -0.001 & -0.013 & -0.002 & 0.074 & -0.032 \\
\hline$[\mathrm{p}=0.165]$ & {$[\mathrm{p}=0.513]$} & {$[\mathrm{p}=0.640]$} & {$[\mathrm{p}=0.521]$} & {$[\mathrm{p}=0.094]$} & {$[\mathrm{p}=0.656]$} & \\
\hline $\begin{array}{l}\text { Number of boys } 15-19 \text { years } \\
\text { old }\end{array}$ & $-0.054^{*}$ & 0.030 & -0.028 & 0.014 & -0.048 & 0.104 \\
\hline$(0.023)$ & $(0.044)$ & $(0.044)$ & $(0.046)$ & $(0.041)$ & $(0.068)$ & \\
\hline $\begin{array}{l}\text { Number of girls } 15-19 \text { years } \\
\text { old }\end{array}$ & 0.021 & 0.069 & -0.003 & 0.058 & 0.062 & 0.080 \\
\hline$(0.037)$ & $(0.072)$ & $(0.047)$ & $(0.048)$ & $(0.052)$ & $(0.149)$ & \\
\hline $\begin{array}{l}\text { Difference in coefficients } \\
\text { (Girls-Boys) }\end{array}$ & 0.075 & 0.039 & 0.025 & 0.044 & 0.110 & -0.024 \\
\hline [p-value for Difference $>0$ ] & {$[\mathrm{p}=0.056]$} & {$[\mathrm{p}=0.257]$} & {$[\mathrm{p}=0.314]$} & {$[\mathrm{p}=0.254]$} & {$[\mathrm{p}=0.061]$} & {$[\mathrm{p}=0.578]$} \\
\hline $\begin{array}{l}\text { Number of boys } 20-24 \text { years } \\
\text { old }\end{array}$ & -0.067 & -0.040 & -0.015 & -0.005 & -0.072 & -0.049 \\
\hline$(0.045)$ & $(0.040)$ & $(0.060)$ & $(0.041)$ & $(0.061)$ & $(0.074)$ & \\
\hline $\begin{array}{l}\text { Number of girls } 20-24 \text { years } \\
\text { old }\end{array}$ & -0.007 & 0.118 & -0.008 & 0.039 & 0.005 & 0.242 \\
\hline$(0.048)$ & $(0.077)$ & $(0.070)$ & $(0.049)$ & $(0.061)$ & $(0.191)$ & \\
\hline $\begin{array}{l}\text { Difference in coefficients } \\
\text { (Girls-Boys) }\end{array}$ & 0.056 & 0.158 & 0.007 & 0.044 & 0.077 & 0.291 \\
\hline [p-value for Difference $>0$ ] & {$[\mathrm{p}=0.172]$} & {$[\mathrm{p}=0.019]$} & {$[\mathrm{p}=0.416]$} & {$[\mathrm{p}=0.234]$} & {$[\mathrm{p}=0.196]$} & {$[\mathrm{p}=0.076]$} \\
\hline Obs. & 9,841 & 6,540 & 5,874 & 4,227 & 3,967 & 2,313 \\
\hline
\end{tabular}

Notes: All of the estimates are derived from fixed-effect models. Control variables are men's and their wives levels of education, men's age, the square of men's age, wealth indicator, and children's employment status. Urban/rural and province weights are applied. Standard errors clustered per sampling cluster are in parentheses. ${ }^{* * *}, * * *$ indicate significance at $1 \%, 5 \%$, and $10 \%$ levels, respectively.

Data Source: Survey of Household's Socioeconomic Characteristics (SHSC), Statistical Center of Iran (SCI).

Breaking down the observed country-wide effects into their urban and rural components provides more insight into men's labor market behavior in relationship to the age and gender of his children. For an urban man, having young children requires more of both labor and nonlabor income regardless of their gender, while having young children has no effect on rural men's labor and nonlabor income. However, consistent with our observation in Section 5.1 that the differential effects of sons and daughter on a man's total income are more resonant in rural areas, a rural man's nonlabor income is greatly influenced by the gender of children who are approaching the age of marriage (i. e., the 20-24 age group). In fact, having a female child within that age group is associated with about 24 percent more nonlabor income for an average rural man, whereas the effect of having a male child in the same age group on his nonlabor income cannot be distinguished from zero. For an urban man however the magnitude of the same effects are very much smaller, at about 4 percent. $^{21}$

\subsection{Alternative Explanations}

The prominent alternative explanation to the dowry effect is that a man who has sons has "helping hands" in increasing his income, which is more pronounced in rural areas. This concern is addressed in our analyses by controlling for children's employment status; as shown in Table 4-Table 6, the differential effects of children's gender on their fathers' income remains significant. Additionally, we test the impact of excluding children's employment status from the regressions on the coefficients of interest (i. e., the effects of children's gender by their age groups on men's income) and observe negligible to no effect.

About 40 percent of the children who are reportedly employed have no reported income. These children are generally denoted as unpaid family workers. Therefore, controlling for children's employment status allows us to account for the contributions of both paid and unpaid employed children. The inclusion of children's income among the explanatory variables - in order to determine the impact of the size of the income of working children on the coefficients of interest - does not change the pattern and magnitude of the results.

The fact that we find children's employment and income to have little to no impact on the coefficients that we interpret as dowry effects is not surprising, knowing that an infrequent number of children in the 15-19 
and 20-24 age groups reported some income and, that any reported income is very small in comparison to their fathers' income. ${ }^{22}$ In urban areas, a 90th-percentile child - that is to say, one who is ranked according to his or her income with respect to other children's income - makes even less than a 10th-percentile man who is ranked according to his income with respect to other men's income. It is generally similar in rural areas: a 90th-percentile rural child makes less than a 20th-percentile rural man. Therefore, the differential effects of children's gender on men's income, especially when the children are closer to the age of marriage, cannot be attributed to children's contribution to their families' income. Although the share of working female children is about two-thirds of that of working male children, and the share of female children with some income is about one-half of that for male children with income, controlling for children's employment and income does not change the pattern in the results.

Old age support could also provide an alternative explanation for the dowry effect (McGarry 1998). A man with sons may need to save less for his old age because sons may contribute more to their parents' livelihood in old age, especially in rural areas. This hypothesis could be tested if the amounts and sources of transfer payments to elderly household heads would have been reported in the data. In the absence of this information, we can look at households in which grandparents are present, as a sign of old age support. In fact, in only 269 of 5,090 households (about 5 percent) are there grandparents present. About 92 percent of elderly parents who are living with their children are female, reflecting the fact that old age support is more applicable to women than men. While the limited information available to us in this regard shows a weak sign of the prevalence of such support, we cannot completely rule out the effect of this factor on the labor market response of a man to his children's gender.

\subsection{Robustness Tests}

The robustness of the results presented in Table 3-Table 6 are examined by using different levels of sample clustering. In practice, the results hold when either no clustering or only clustering per province is applied. In addition, we reproduced the results presented in Table 3-Table 6 for no sampling weights, and found that neither the pattern of the results nor the magnitude of the coefficients changed noticeably. As another robustness test, we re-estimated the variations of eq. 4 that are estimated in this study for various age groups, and observed similar patterns in the results. Especially, we chose the 0-7, 8-18, and 19-24 age groups, which represent the pre-school age, school age, and post-school age, respectively.

The age-specific nature of our analyses leaves little room for examining alternative indicators of children's gender. For example, in eq. 4], the numbers of male and female children can be replaced with dummy variables for the numbers of male and female children. More specifically, $N B O Y_{k, i t}$ can be replaced with $N B O Y 0_{k, i t}$, $N B O Y 1_{k, i t}$, and NBOY $2_{k, i t}$ as indicators of no, one, and more than one male child(ren) in the age group $k$ for man $i$. Likewise, NGIRL $L_{k, i t}$ can be replaced with $N G I R L 0_{k, i t}, N G I R L 1_{k, i t}$, and NGIRL2 ${ }_{k, i t}$ as indicators of no, one, and more than one female child(ren) in the age group $k$ for man $i$. However, given our not-large sample size and the scarcity of cases in which a man has two or more children of the same gender in one age group, the statistical power of the estimated coefficients are rendered invalid. Nonetheless, this practice indicates that the estimated coefficients for the effect of one more male and one more female child in age group $k$ (i. e., the coefficients for NBOY $_{k, i t}$ and NGIRL $L_{k, i t}$ as presented in Table 4-Table 6) can also be interpreted as the effects of having male and female children within that age group.

\section{Concluding Remarks}

We showed that the presence of children in a family significantly increased Iranian men's work hours and income in early 1990s. We also showed that Iranian men with female children generated more income than those with male children.

We provided evidence on the remarkable burden of dowry, which was widely practiced in early 1990s, and hypothesized that the tradition as the driving force behind these results. The age-specific pattern of the effect of children's gender on men's income conforms with the hypothesis. Specifically, we found that the effect of presence of female children on men's income was more significant as they approached the age of marriage. Furthermore, we found that the age-specific pattern was more pronounced for rural men. Examining the agespecific effects on labor and nonlabor income provided further evidence in support of the dowry hypothesis.

Several mechanisms for the effect of dowry on a man's income can be suggested. A generous dowry could guarantee a safe future for a female child - who, in a traditional developing society such as early 1990s Iran, faced fewer job opportunities than a male child - by attracting financially strong sons-in-laws. Consistent with this explanation, dowry effects were found stronger in rural areas. The stronger dowry effects also hint at its 
role as an intra-family wealth distribution tool in an agricultural society where sons receive a larger share of their parents' land and daughters are instead compensated by dowry. Additionally, in a society where wellfunctioning capital markets are absent, dowry can also signal a family's economic affluence.

While the dowry is still being practiced in many countries from South and Central Asia to Eastern Europe and affects millions of people's lives, there is little known about its effects on men and women's labor supply, their intra-family interactions, and women's welfare. To improve our knowledge of the key marriage institution and its implications in tandem with the economic evolution of societies, long and extensive longitudinal surveys are required. Better understanding of dowry would then have important policy implications. One interesting policy debate is whether families with daughters receive public assistance, such as tax credits, to help them with the provision of dowry.

The short four-year panel dataset used herein also does not provide sufficient time variation in studying families' incomes and savings; ultimately, many questions are put forward and remain unanswered by this study. The most important question is whether there are any significant effects of dowry on daughters' future life - that is, returns to dowry. The other question relates to changes to education or labor-force participation rates among women: when women are becoming increasingly more educated in both urban and rural areas, fathers' job market responses to the presence of female children in their families may change.

\section{Acknowledgments}

We thank the anonymous reviewer for the careful reading of the paper and insightful comments. We also thank Dan Bernhardt, Hadi S. Esfahani, Nader Habibi, Cynthia D. Howson, Pierre Ly, Elaina Rose, Djavad Salehi-Isfahani, Mohammad Tabibian, and the seminar participants in the $40^{\text {th }}$ Annual Conference of the Eastern Economic Association, the $3^{\text {rd }}$ International Conference on the Iranian Economy, and the Department of Economics of the University of Illinois at Urbana-Champaign Ph.D. workshops for their helpful comments.

\section{Notes}

${ }^{1}$ The related literature focuses on only one of the two issues. For example, although Lundberg and Rose (2002) and Choi, Joesch, and Lundberg (2008) show that US and German men increase their labor market activities when they have sons rather than daughters, they do not empirically examine the possible motives behind this behavior. The motives are usually inferred from studies that investigate men's nonlabor market responses to their children's gender - such as tendency to propose, length of marriage, or predisposition to divorce - and the intra-household allocation of resources (Dahl and Moretti 2008; Deaton 1989). However, explanations for men's biased responses to their children's gender in these latter studies may not necessarily apply to their labor market responses.

${ }^{2}$ There exists anecdotal evidence of colossal dowry costs that has resulted in delays in marriages in Iran. See the following article from The Guardian as an example: http:/ /www.theguardian.com/world/iran-blog/2014/apr/07/the-rising-price-of-love-in-iran

${ }^{3}$ The graphs and numbers are calculated by authors from Iran Household Budget Survey for the year 1992, conducted by Iran Statistical Center available at: https://www.amar.org.ir/english/.

${ }^{4}$ The importance of household fixed-effects in this context is highlighted by Subramaniam (1996) and demonstrated in other studies, such as those of Lundberg and Rose (2002) and Choi, Joesch, and Lundberg (2008).

${ }^{5}$ Dahl and Moretti (2008), using 1960-2000 US census data, find that the probability of a woman never marrying will increases if her first child is a female, and if she is married, the probability of divorce increases if the woman's first child is a female. If she is divorced, the probability of having custody of a female child is higher for the woman. In line with Dahl and Moretti (2008), Morgan, Lye, and Condron (1988), and Mott (1994) find that the odds of the persistence of a marriage significantly increase with the birth of a male rather than a female child. Teachman and Schollaert (1989) also document that the likelihood of having a second child increases if the first child is female. The findings of all of these studies suggest that men prefer male children.

${ }^{6}$ Studies in some countries find no evidence of son preference in household expenditure: Thailand and Ivory Coast (Deaton 1989), Vietnam (Haughton and Haughton 1997), and rural Pakistan (Bhalotra and Attfield 1998). On the other hand, son preference in resource allocation has been documented in rural china (Burgess and Zhuang 2003; Gong, Van Soest, and Zhang 2005), Ethiopia (Koohi-Kamali 2008; 
Dercon and Singh 2013), India (Asfaw, Lamanna, and Klasen 2010; Dercon and Singh 2013; and Barcellos, Carvalho, and Lleras-Muney 2014), and Indonesia (Pollani 2014).

${ }^{7}$ This dataset has also been used by other researchers. For example, Salehi-Isfahani and Majbouri (2013) use it to study the dynamic of poverty in Iran.

${ }^{8}$ There is another panel from early 2000s covering almost the same types of variables, but for three reasons we prefer to use the 1992-1995 survey. First, the main reason is that in early 1990s there was more variation in young individuals' behavior in job and marital markets. At the time, there still were many traditional families believing that the best thing they could do for their girls was to prepare them for a good marriage. This picture was changing quickly as more girls were seeking education and thus having new plans for their futures a decade later. Therefore, the early 1990s panel is more suitable for testing the theory than later panels. Second, the early 2000s panel is shorter, covering three years from 2000 to 2002. Third, the last year of data in the early 2000s panel has many missing parts and our effort to acquire the full version of the data remained unsuccessful.

${ }^{9}$ Interviews took place in November of each year.

${ }^{10}$ The inclusion of a wealth indicator is important in accounting for variations in households' well-being. This wealth indicator, the rental value of a household's dwelling, is different from the rental income from real estate properties owned by a man as part of the miscellaneous forms of income that are included in the total income, which is the main labor outcome variable of interest in this study.

${ }^{11}$ One potential case is that a man who is more likely to have female children may perform differently in the labor market than a man who is more likely to have male children.

${ }^{12}$ Controlling for a man's age is critical to capturing the dynamic of his income by age.

${ }^{13}$ According to the statistics captured through the 1991 and 1996 censuses, the average ages of boys and girls at their first marriage in 1991 (one year before the first round of the panel survey was conducted) were 24 and 21, respectively; these averages rose to 25 and 22, respectively, in 1996 (one year after the last round of the panel survey was conducted). These numbers suggest that when the survey information was collected, the majority of Iranian families expected their children to marry in the first half of their twenties. Thus, families are preparing for the financial necessities of their children's marriage - especially dowry for female children - before they reach this age range. Examinations of the employment status and income of unmarried children above this age range show that a large share of them had entered the job market and, thus, relieved the household of a part of the financial burden. In addition, the probability of remaining unmarried increases after the late 20s, and the "lemon effect" may dominate other factors. These considerations suggest that having older children may distort the results of our analyses.

${ }^{14}$ The largest share of miscellaneous income comes from renting real estate properties. This further justifies the use of miscellaneous forms of income as an indicator of the lifelong labor market efforts of a man.

${ }^{15}$ Weekly work hours are calculated by multiplying the average work hours per day by the average work days per week. The reason for preferring this variable over average work hours per day and average work days per week is the provision of greater statistical variation. In fact, the average work hours per day has three heaping points $(4,6$, and 8$)$ and the average work days per week has two heaping points (4 and 6).

${ }^{16}$ In the dataset, household locations cannot be tracked below the province level.

${ }^{17} \mathrm{~A}$ man's weekly work hours is not a suitable dependent variable for the purpose of the analyses discussed in this section. First, this variable reflects only short-term fluctuations in a man's employment status. Second, it does not present enough variations within each age group.

${ }^{18}$ Parents who keep their married children in the household and share their belongings with them may have incentives that differ from those of other parents. Additionally, married children who live outside a household may contribute to their former households through cash or in-kind transfers. We exclude these types of households from our estimation sample.

${ }^{19}$ Since dowry-related expenditures are not reported in the panel survey data used in our estimations, we use Iranian household budget surveys from the same period as the panel survey; we find that the expenses are considerably large. Appendix A presents a discussion on the structure of dowry expenses, families' plans to provide dowry, and approximations of the size of a major dowry item.

${ }^{20}$ The average and median annual inflation rates from 1976 (i. e., 15 years before conducting the first round of the 1992-1995 panel survey) until 1995 were about 21.75 percent and 22.8 percent, respectively, according to the consumer price indices reported by the Central Bank of Iran.

${ }^{21}$ The obtained results also agree with what we detect in Appendix A, that households generally do not present gradual dowry-gathering behavior, but rather gradual dowry-saving behavior.

${ }^{22}$ Because of the infrequency of income reporting by children who in age groups 15-19 and 20-24, we have not included children's income among the regressors of our main regressions whose results are reported in Tables 3-6.

\section{References}

Asfaw, A., F. Lamanna, and S. Klasen. 2010. “Cender Gap in Parents' Financing Strategy for Hospitalization of Their Children: Evidence from India." Health Economics 19 (3): 265-279.

Azimi, E. 2014;"Intra-Household Resource Allocation and Cender Bias in Iran.” Working Paper, Department of Economics, Simon Fraser University.

Barcellos, S.H., L.S. Carvalho, and A. Lleras-Muney. 2014. “Child Gender and Parental Investments in India: Are Boys and Cirls Treated Differently?" American Economic Journal: Applied Economics 6 (1): 157-189.

Bhalotra, S., and C. Attfield. 1998. "Intrahousehold Resource Allocation in Rural Pakistan: A Semiparametric Analysis." Journal of Applied Econometrics 13 (5): 463-480.

Burgess, R., and J. Zhuang. 2003; “Modernisation and Son Preference.” STICERD, Development Economics Discussion Paper 29, London School of Economics.

Choi, H. -J., J. M. Joesch, and S. Lundberg. 2008. “Sons, Daughters, Wives, and the Labour Market Outcomes of West Cerman Men." Labour Economics 15 (5): 795-811.

Dahl, G.B., and E. Moretti. 2008. “The Demand for Sons." Review of Economic Studies 75 (4): 1085-1120.

Deaton, A 1989. “Looking for Boys-Cirls Discrimination in Household Expenditure Data." World Bank Economic Review 3 (1): 1-15.

Deolalikar, A., and E. Rose. 1998. “Cender and Savings in Rural India.” Journal of Population Economics 11 (4): 453-470. 
Dercon, S., and A. Singh. 2013. "From Nutrition to Aspirations and Self-Efficacy: Cender Bias over Time among Children in Four Countries." World Development 45: 31-50.

Cong, X., A. Van Soest, and P. Zhang. 2005. “The Effects of Cender of Children on Expenditure Patterns in Rural China: A Semi-Parametric Analysis." Journal of Applied Econometrics 20 (4): 509-527.

Haughton, D., and J. Haughton. 1997. "Explaining Child Nutrition in Vietnam." Economic Development and Cultural Change 45 (3): 541-556.

Koohi-Kamali, F 2008; "Intra-Household Inequality and Child Gender Bias in Ethiopia." Policy Research Working Paper 475, World Bank.

Koohi-Kamali, F 2011. "The Adult Coods Approach to Child Cender Bias: Evidence from Iran." Journal of Applied Business Research 27 (4): $22-26$.

Lundberg, S., and E. Rose. 2002. "The Effect of Sons and Daughters on Men's Labor Supply and Wages." Review of Economics and Statistics 84 (2): $251-268$.

Maralani, V 2008. "The Changing Relationship between Family Size and Educational Attainment over the Course of Socioeconomic Development: Evidence from Indonesia." Demography 45 (3): 693-717.

McGarry, K1998. “Caring for the Elderly: The Role of Adult Children." In Inquiries in the Economics of Aging., edited by D.A. Wise, 133-163. Chicago: University of Chicago Press.

Morgan, S.P., D. Lye, and G. Condron. 1988. “Sons, Daughters and the Risk of Marital Disruption." American Journal of Sociology 94 (1): 110-129.

Mott, F.L 1994. “Sons, Daughters and Father's Absence: Differentials in Father-Leaving Probabilities and In-Home Environments." Journal of Family Issues 15 (1): 97-128.

Pollani, C 2014; “Childhood Health and the Wantedness of Male and Female Children." Working Paper, Department of Economics, University of Maryland.

Rose, E 2000. “Cender Bias, Credit Constraints and Time Allocation in Rural India.” Economic Journal 110 (465): 738-758.

Salehi-Isfahni, D., and M. Majbouri. 2013. “Mobility and Dynamics of Poverty in Iran: Evidence from 1992-1995 Panel Survey in Iran." Quarterly Review of Economics and Finance 53 (3): 257-267.

Subramaniam, R 1996. “Cender-Bias in India: The Importance of Household Fixed-Effects.” Oxford Economic Papers, New Series 48 (2): 280-299.

Teachman, J.D., and P.T. Schollaert. 1989. “Cender of Children and Birth Timing.” Demography 26 (3): 411-423.

World Bank. 2012. World Development Report 2012: Gender Equality and Development Washington, DC: World Bank.

\section{Appendix A: An approximation of dowry expenditures}

In this appendix, we use Iranian household budget surveys, Household Income and Expenditure Survey (HIES), to provide an approximation of the magnitude of dowry expenditures. ${ }^{23}$ The surveys are available from 1984 onward, but we choose 1991-2003 surveys because they report households' expenditures on one dowry item: large kitchen appliances such as refrigerator, freezer, washer, dish washer, meat grinder, juicer, and the likes that are purchased for dowry. Large kitchen appliances are among the main components of a typical dowry, and households' expenditures on these items can provide an indicator of the burden of dowry on households. Fortunately, the time period for which the dowry-related item is reported in the HIES coincides with the period covered by the panel survey data used in this study's estimations and analyses.

The reported dowry-related expenditures can serve as an indicator of the size of a dowry only if they present a one-time dowry purchase and not a gradual dowry gathering. In fact, a household with a female child may decide to gather large kitchen items throughout a long period of time or, alternatively, decide to save or invest the equivalent money and purchase the items when the child marries. If the household is a gradual dowry gatherer, the reported expenditures underestimate the costs of large kitchen appliances and, in turn, the total cost of the dowry. Therefore, we first determine which behavior is pursued by households.

If households that have unmarried female children usually gather large kitchen items, then it is expected that a representative share of households reports such expenditures. In the followings, the representative range for this share is obtained. According to Iran's National Organization of Civil Records (NOCR) and the statistical summaries of the 1991 and 1996 censuses, females' average age at their first marriage in early 1990s was between 20 and 22. If gradual dowry gathering is prevalent, then the majority of households with female children under 20 are expected to report dowry-related expenditures.

The HIES data show that approximately 66,56 , and 44 percent of the households have at least one female child within the age groups 0-19, 0-14, and 10-19, respectively. Any of these numbers can provide an upper bound for the share of households showing gradual dowry gathering behavior. Among these numbers, we take 44 percent as a conservative proxy. As a lower bond for the share, we take the share of households with only one female child within the age group 10-19; that number is 21 percent. If dowry gathering behavior is prevalent, then it is expected that approximately 21 to 44 percent of households report some dowry-related expenditures. However, among the 263,183 households surveyed from 1991 to 2003, only 6,691 households reported dowry-related expenditures ( 2.5 percent). For a closer picture, we select subsamples of the households with female children only within the age groups $0-4,5-9,10-14,15-19$, and 20-24, and we calculate the same rate for each subsample. The rates are $0.3,1.0,2.9,5.5$, and 5.5 percent, respectively. Comparing these ratios 
with the range of ratios that imply the prevalence of dowry gathering behavior (21-44 percent) clearly shows that dowry gathering behavior is not dominant. ${ }^{24}$

If gradual dowry gathering is not commonplace and dowry is mainly purchased around the time of marriage, it is expected that the ratio of the number of households that reported dowry-related expenditures to the total number of households with female children within the age groups 15-19 or 20-24 resembles the rate of household formation in the country. According to the HIES datasets, the first ratio is about 5.5 percent for both age groups. To find the second ratio, i. e. the rate of household formation at the same time period, we compute the ratio of the number of marriages to the total number of households. Number of marriages is provided by the National Organization of Civil Registration (NOCR). The total number of households is extrapolated using the data from the 1991, 1996, and 2006 censuses. The computed ratios vary between 4.4 and 5.3. These ratios are unsurprisingly close the ratio of dowry reporting. We conclude that gradual dowry gathering is not prevalent.

If dowry gathering behavior is not confirmed, then households purchase the whole dowry around the time of the marriage of their female children. As a result, a household's expenditures on large kitchen appliances for dowry represent its total expenditures on such items. Now, we compute the average ratio of this expenditures over total non-dowry expenditures for households with female children within the ages 15 and 24. The ratio is about 23 percent in 1991-2003. In the period that coincides with the timespan of our panel dataset, 1992 to 1995, the ratio is about 25 percent. In other words, the dowry-related expenditures reported by households, which include only large kitchen appliances, compromise about 25 percent of all other expenditures of households. Since a typical dowry consists of many other items, not included the costs of marriage ceremonies, we conclude that the cost of a complete dowry is so sizable that households must plan years in advance to provide it.

\section{Appendix B: Test of selective abortion}

Children's gender composition is not random in the existence of selective abortion. Families may avoid having female children because of the expected burden of dowry and abort them before their birth. This can cause a serious endogeneity problem for the results of this study. In this appendix, we use information from different sources to illustrate that there is no evidence of selective abortion in Iran. In fact, the male-to-female ratio in Iran is very close to its natural non-intervened value, 1.06 .

Our different sources of data are censuses, household budget surveys (HIES), and birth registrations. We use data from 1986, 1996, and 2006 censuses to compute male-to-female ratio at the population level. The abundance of data allows for computing the ratio for exact ages in both rural and urban areas. The results, presented in Figure 2)-(c), show no evidence of an interfering tendency toward boys at birth at the aggregate level. The ratio was volatile in 1986 but became more stable in 1996 and 2006 at approximately 1.05. Despite some slight volatilities, the figures do not show any evidence of gender selection over years. 
(a)
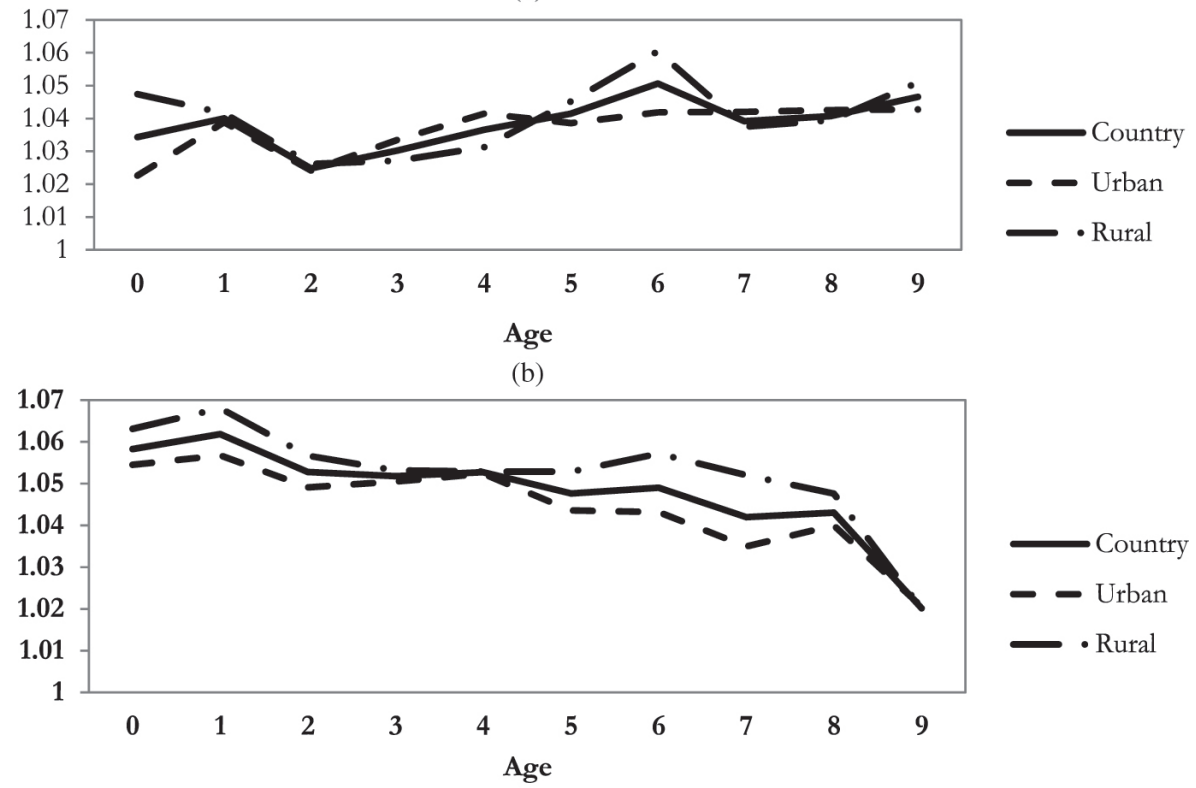

(c)

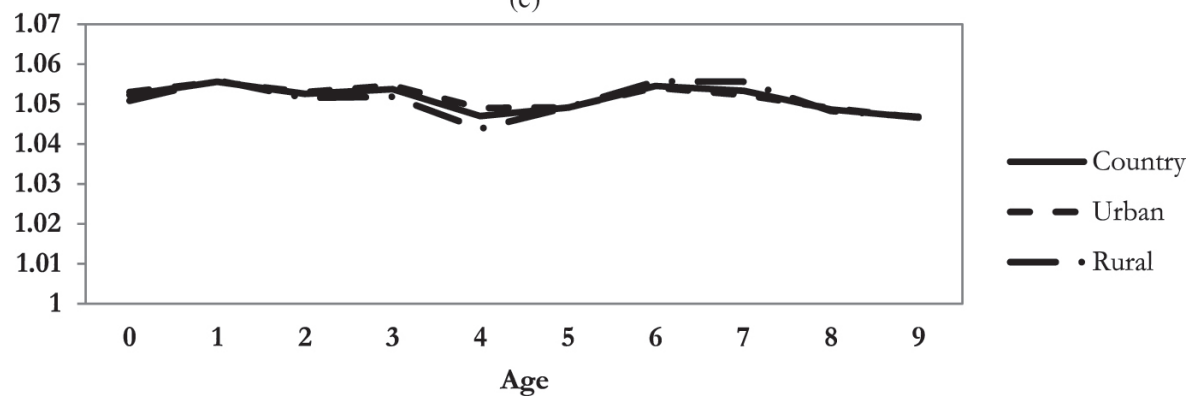

Figure 2: (a) Male-to-female ratio by age in census 1986; (b): male-to-female ratio by age in census 1996; (c): male-tofemale ratio by age in census 2006.

Figure 3 shows male-to-female ratios at the age range 0-9 in all available HIES surveys. Because the assigned age to children with 365 or less days of age is 0 in some surveys and 1 in others, we calculate the ratio for this wider age range. We do not compute separated ratios for urban and rural areas to obtain sufficient observations for the age range, especially in the earlier surveys. As shown in Figure 3, the ratio fluctuates between 0.99 and 1.08 but shows more stability from 1992 with slight variations around 1.06.

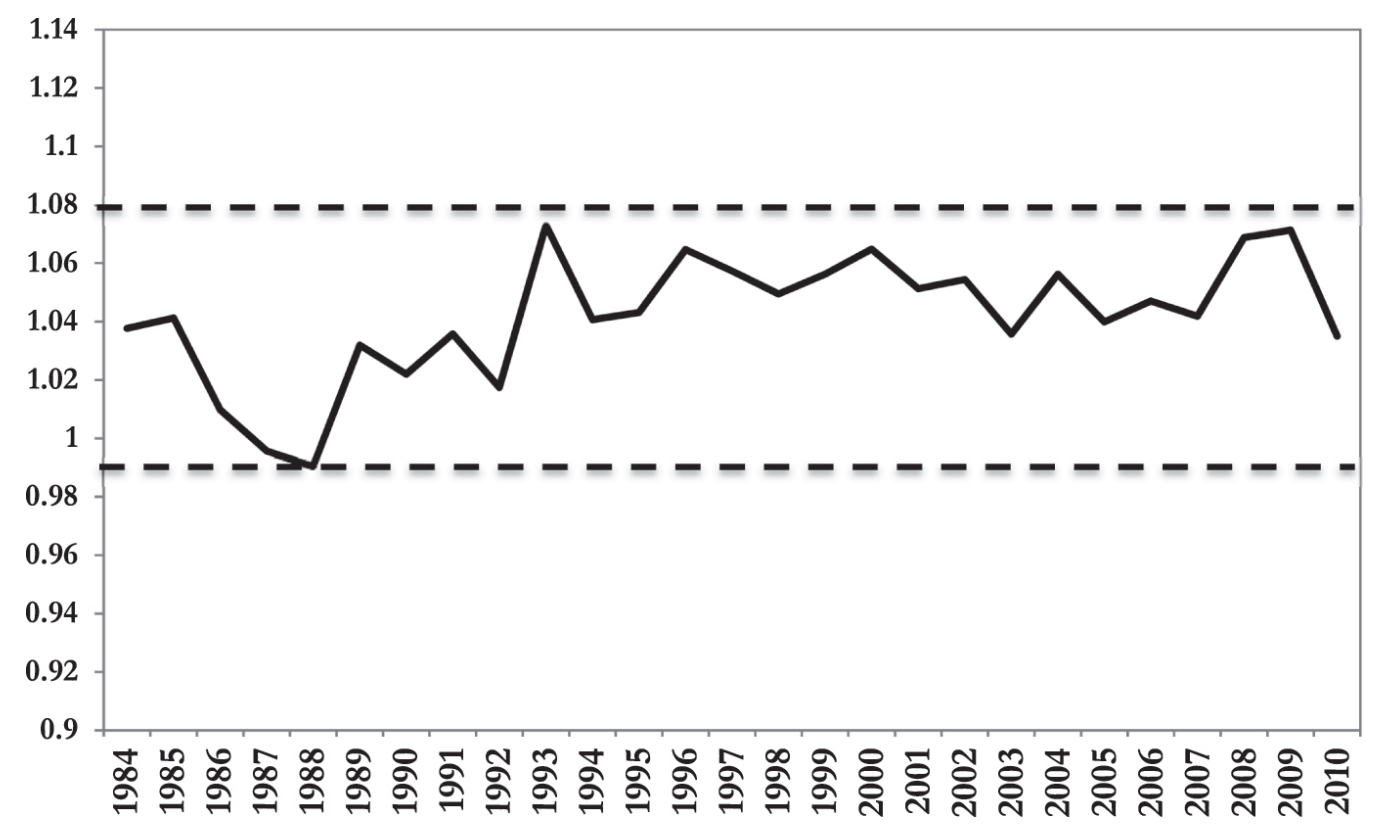

Figure 3: Male-to-female ratio in age range 0-9 according to different years' household budget surveys. 
The data from the National Organization for Civil Registration (NOCR) provides further proof for the nonexistence of selective abortion in Iran. If selective abortion exists, then less female birth registrations are expected. This, however, is not confirmed by the registered birth data. Figure 4, which depicts the male-tofemale ratios for 1989 to 2009, shows that the ratios are less than 1.06 during the whole period in both urban and rural areas.

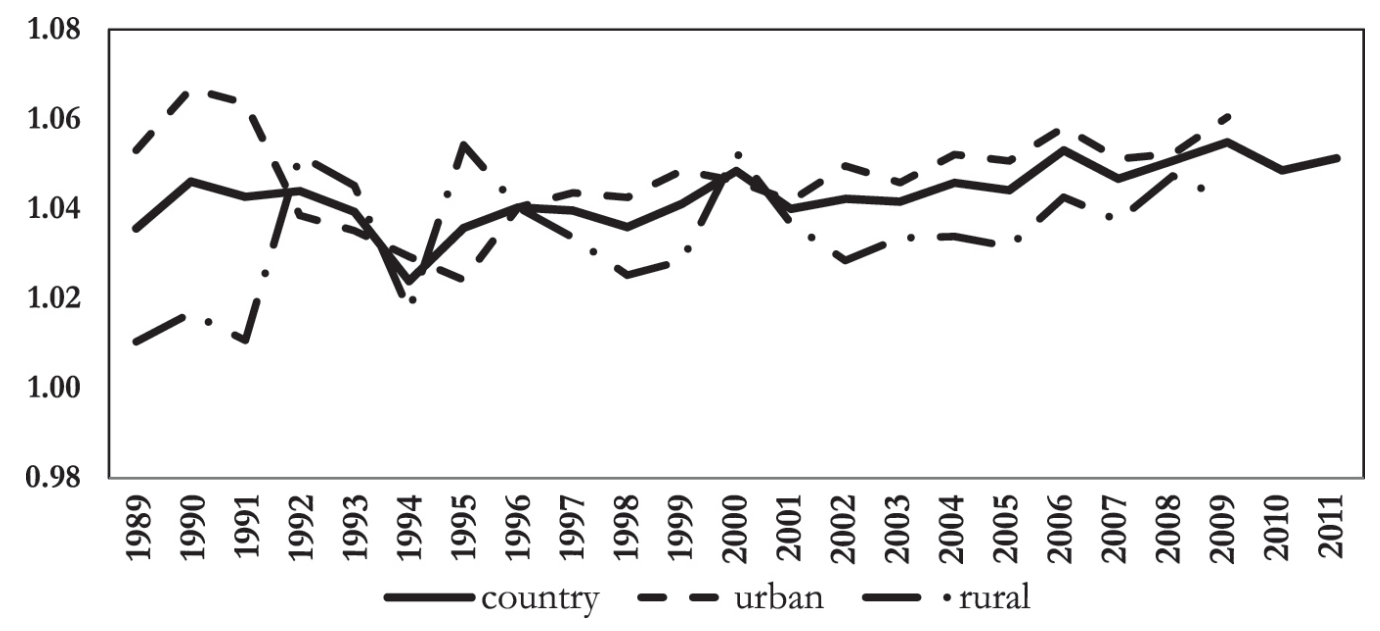

Figure 4: Male-to-female ratio at birth by year according to the registered birth information. 